\title{
THE DWELLERS’ ATTACHMENT TO JOGLO HOUSES IN KOTAGEDE
}

\author{
Deny Prastika Candra ${ }^{1 *}$, Wara Indira Rukmi ${ }^{1}$, Deni Agus Setyono ${ }^{1}$ \\ ${ }^{1}$ Urban and Regional Planning Department, Brawijaya University, \\ Jl. Mayjen Haryono 167, Malang 65145, INDONESIA \\ *Corresponding author; Email: denyprastika@student.ub.ac.id
}

\begin{abstract}
The number of Joglo houses in existence has decreased in recent years. Any effort to conserve the remaining Joglo depends on the behavior of the dwellers in maintaining and utilizing Joglo properly. People who have stronger levels of place attachment tend to support conserving that place. Place attachment can be explained in three dimensions: the person, the place, and the psychological process. This study explores the attachment of the dwellers to their Joglo by using PLS-PM analysis to understand the relationships among these dimensions. The results show that the person and place dimensions have a positive effect on each of the aspects of the dimension of psychological process, but not all dimensions have a significant effect and the effect of each dimension varies. The evaluation of the model concludes that it has a high ability to explain the empirical conditions of the dweller's place attachment to their Joglo.
\end{abstract}

Keywords: Place attachment; Joglo; PLS-PM.

\section{INTRODUCTION}

In $1532 \mathrm{AD}$, Kotagede was part of the capital of the Mataram Sultanate. The capital was built during the reigns of $\mathrm{Ki}$ Ageng Pamanahan and his son Penembahan Senopati (Yetti, 2018). As a former capital city, Kotagede has various historical features, in both socio-cultural life and buildings with traditional architectural characteristics (Jogja Heritage Society, 2007). Joglo is a building style that has historical and cultural value. Joglo is a traditional Javanese house building style, which has a roof shape resembling a mountain (pyramid), a symbol of tumpang sari (Subiyantoro, 2012). Joglo have several components, including pendhapa, pringgitan, dalem, a kitchen, gandhok, and gadri (Ronald, 2005). Joglo also refers to a traditional Javanese house, which is aligned spatially on a north-south cosmological axis. The north direction refers to Mount Merapi, which is associated with natural forces, while the south faces the south sea, believed to be the residence of Nyi Roro Kidul (the queen of the southern sea). The people of Yogyakarta firmly adopted this belief during the Mataram Sultanate era, so almost all Joglo are oriented toward the south. In recent years, the number of Joglo has decreased. A survey conducted in 2019 found the number of Joglo in Kotagede to be 76 units.

The decline in the number of Joglo is a result of the partial or complete conversion of the buildings into modern houses. Other Joglo have been sold and moved out of Kotagede (Jogja Heritage Society, 2007). The 2006 earthquake also damaged several remaining Joglo, which forced reconstruction that often changed the authenticity of the Joglo (Utomo,
2014). These developments make it necessary to preserve the remaining Joglo, which contribute to the identification of Kotagede as a Cultural Heritage Area (SK Gub. DIY 186 / KEP / 2011).

Table 1. Number of Joglo in Kotagede in 2019

\begin{tabular}{|c|c|c|c|}
\hline \multirow[b]{2}{*}{ Sub-district } & \multicolumn{2}{|c|}{ Condition } & \multirow[b]{2}{*}{$\begin{array}{l}\text { Total } \\
\text { (unit) }\end{array}$} \\
\hline & $\begin{array}{l}\text { Occupied } \\
\text { (unit) }\end{array}$ & $\begin{array}{l}\text { Inhabited } \\
\text { (unit) }\end{array}$ & \\
\hline Rejowinangun & 2 & & 2 \\
\hline Prenggan & 29 & & 30 \\
\hline Purbayan & 41 & & 44 \\
\hline Total (unit) & 72 & & 76 \\
\hline
\end{tabular}

Joglo house preservation efforts depend on the behavior of the dwellers in maintaining and utilizing Joglo appropriately. In such cases, place attachment has an important influence on conservation efforts (Vaske \& Kobrin in Scannell \& Gifford, 2014). Place attachment is an emotional relationship that is formed by an individual to a setting/place and results in significant meaning for the individual through interaction (Milligan in Inalhan \& Finch, 2004). Riley in Altman and Low (1992) states that such attachment is not only to a landscape or physical entity but also to meanings and experiences in the place that involve relationships with other people. Therefore, place attachment is a multidimensional concept (Yuksel et al., 2010).

Scannell and Gifford (2010) explain that there are three dimensional frameworks for place attachment: the person, the place, and the psychological process. The person dimension describes the attachment based on individual factors (e.g., time), collective factors (e.g., cultural significance or 
beliefs), or a combination of both (Scannell \& Gifford, 2014). The dimension of place includes social (e.g., social interaction) and physical (e.g., residential ownership) factors (Scannell \& Gifford, 2010).

The psychological process dimension of place attachment consists of three aspects based on theoretical and operational definitions, which are affective, cognitive, and conative (Low \& Altman, 1992; Jorgensen \& Stedman, 2001). The affective aspects refer to social bonding (Chen \& Segota, 2015). Social bonding is the emotion of ownership or connections among people based on common characteristics (Chen \& Segota, 2015; Kasarda \& Janowitz in Goussous \& Al-Hammadi, 2018). The cognitive aspects connect the physical environment with self-conceptualization (Kyle et al. 2004). Place identity is a symbolic and emotional bond to a place over time (Stedman, 2002). The conative aspects concern place dependence (Kyle et al., 2004; Chen \& Segota, 2015), a functional bond associated with certain activities or experiences that a person can do only in that place (Williams et al., 1992).

This study seeks to determine the correlation between the place attachment frameworks and the dwellers of Joglo based on the person, place, and psychological process dimensions. It will describe the correlation through a model based on the results of the PLS-PM (Partial Least Square-Path Modeling) analysis.

\section{RESEARCH METHOD}

The research method employs information from a questionnaire given to people living in Joglo in Kotagede. The responses to the questionnaire provided categorical data related to the person and place dimensions and ordinal data related to the psychological process dimension.

\section{Research Variables}

The research variables for the study of attachment to Joglo as a dwelling in Kotagede were determined based on the relevant theory. To meet the research objectives, researchers used latent variables (constructs) and manifest variables (indicators).

\section{Method of Data Collection}

This study used a primary survey to collect data. The researchers chose a semi-open questionnaire as an instrument for data collection and arranged the questions based on the indicators of each variable to ask respondents for information and perceptions related to their attachment to Joglo they live in.
Table 2. Research Variables

\begin{tabular}{|c|c|c|c|}
\hline $\begin{array}{l}\text { Construct } \\
\text { (Latent } \\
\text { Variable) }\end{array}$ & Code & $\begin{array}{l}\text { Indicator } \\
\text { (Manifest } \\
\text { Variable) }\end{array}$ & Source \\
\hline \multirow[t]{14}{*}{ Person } & $\mathrm{X} 1.1$ & Age & $\begin{array}{l}\text { Altman \& Low, } \\
1992\end{array}$ \\
\hline & $\mathrm{X} 1.2$ & Length of Stay & Lewicka, 2014 \\
\hline & $\mathrm{X} 1.3$ & Sex & Lewicka, 2005 \\
\hline & $\mathrm{X} 1.4$ & Gender Roles & Lewicka, 2005 \\
\hline & $\mathrm{X} 1.5$ & Level of & Scannel \& \\
\hline & X1.6 & $\begin{array}{l}\text { Eaucation } \\
\text { Occupation }\end{array}$ & \\
\hline & $\mathrm{X} 1.7$ & Income & \\
\hline & $\mathrm{X} 1.8$ & Working hours & \\
\hline & X1.9 & $\begin{array}{l}\text { Number of } \\
\text { Working days }\end{array}$ & \\
\hline & $\mathrm{X} 1.10$ & $\begin{array}{l}\text { Status of } \\
\text { Ownership }\end{array}$ & \\
\hline & $\mathrm{X} 1.11$ & Cultural/Ritual & Mazumdar \& \\
\hline & & Practices & Mazumdar, 2004 \\
\hline & $\mathrm{X} 1.12$ & $\begin{array}{l}\text { Number of } \\
\text { Family members }\end{array}$ & $\begin{array}{l}\text { Altman \& Low, } \\
1992\end{array}$ \\
\hline & $\mathrm{X} 1.13$ & $\begin{array}{l}\text { History of } \\
\text { Disaster Impact }\end{array}$ & $\begin{array}{l}\text { Altman \& Low, } \\
1992\end{array}$ \\
\hline \multirow[t]{4}{*}{ Place } & $\mathrm{X} 2.1$ & $\begin{array}{l}\text { Intensity of } \\
\text { Social } \\
\text { interactions }\end{array}$ & Fried, 2000 \\
\hline & $\mathrm{X} 2.2$ & $\begin{array}{l}\text { Number of } \\
\text { Dwelling }\end{array}$ & $\begin{array}{l}\text { Scannel \& } \\
\text { Gifford, } 2010\end{array}$ \\
\hline & $\mathrm{X} 2.3$ & Stay Plan & \\
\hline & $\mathrm{X} 2.4$ & $\begin{array}{l}\text { Proximity to } \\
\text { another Joglo }\end{array}$ & Fried, 2000 \\
\hline \multicolumn{4}{|c|}{ Psychological Process } \\
\hline \multirow[t]{4}{*}{ Affective } & Y3.1 & Memories & Goussous \& \\
\hline & Y3.2 & Residency & Hammadi, 2018; \\
\hline & Y3.3 & Users & Chen \& Segota, \\
\hline & Y3.4 & Special Bond & 2015 \\
\hline \multirow[t]{4}{*}{ Cognitive } & Y3.5 & Meaning & Goussous \& \\
\hline & Y3.6 & Identify & Hammadi, 2018; \\
\hline & Y3.7 & Pride & Chen \& Segota, \\
\hline & Y3.8 & Commitment & 2015 \\
\hline \multirow[t]{4}{*}{ Conative } & Y3.9 & Activities & William \& Vaske, \\
\hline & Y3.10 & Best & 2003; Ujang, \\
\hline & Y3.11 & Preference & 2012; Goussous \& \\
\hline & Y3.12 & Satisfaction & $\begin{array}{l}\text { Hammadi, 2018; } \\
\text { Chen \& Segota, } \\
2015\end{array}$ \\
\hline
\end{tabular}

In determining the sample size, the researchers did not have definite data regarding the number of residents who live in Joglo. The researchers only had data on the number of Joglo in Kotagede, where there were 76 Joglo spread across three urban villages that became the research locations. Two (2) houses were located in the Rejowinangun sub-district, thirty (30) in Prenggan village, and the remaining forty-four (44) in 


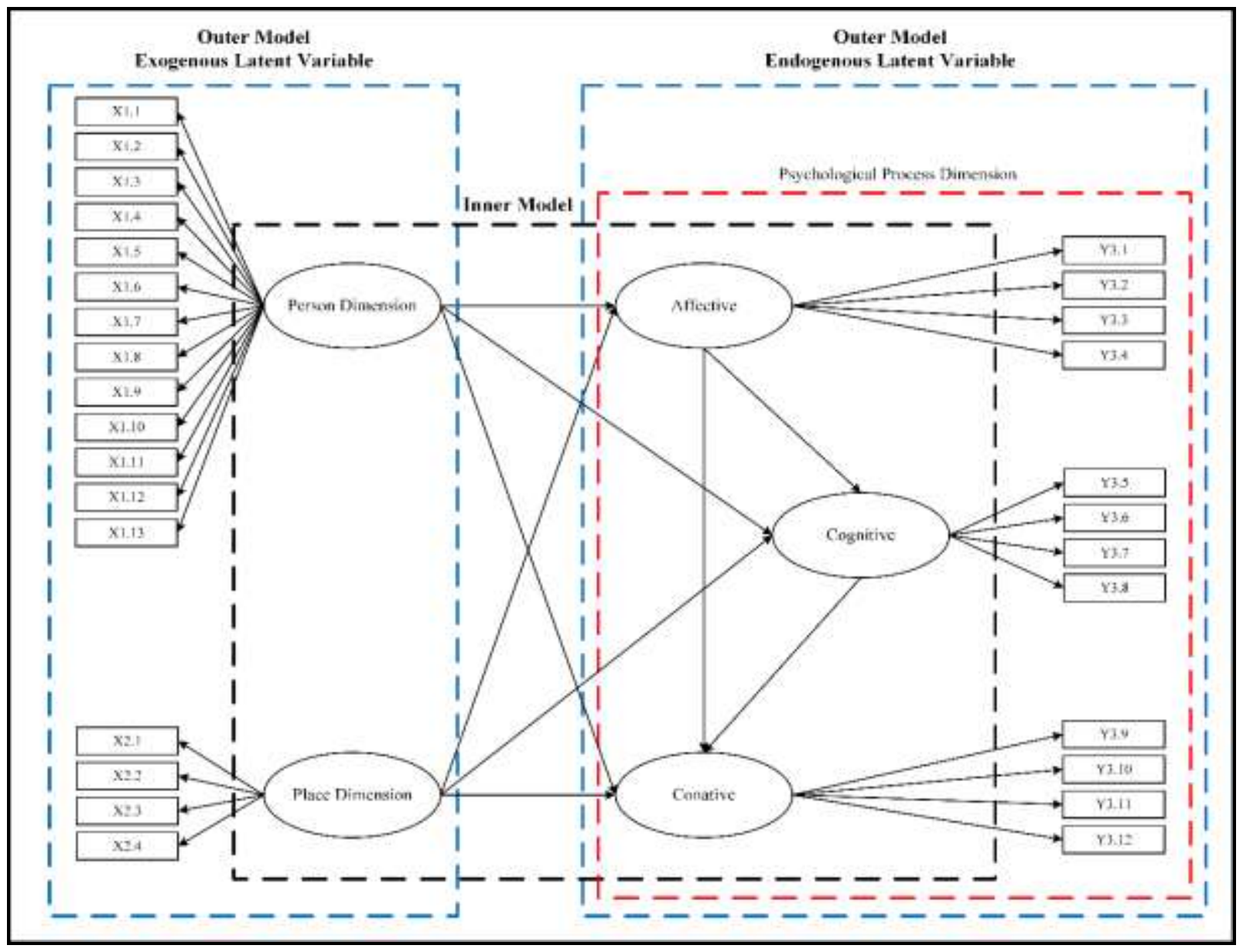

Fig.1. Model Plan

Purbayan village. However, only seventy-two (72) Joglo were inhabited. Because the total number of surviving Joglo is unknown, the researchers used the purposive sampling technique, a nonprobability sampling procedure. An adult family member over twenty-five (25) years of age represented each Joglo in this purposive sampling. Thus, this study considered seventy-two (72) respondents, each representing an inhabited Joglo.

\section{PLS-PM (Partial Least Square-Path Modeling) Analysis}

PLS-PM is a form of Structural Equation Modeling (SEM). In contrast to covariance-based SEM, PLS-PM is based on variance. PLS-PM can evaluate simultaneously both the measurement model and the structural model (Abdillah \& Jogiyanto, 2015). The advantage of PLS-PM for this study is that it is not based on various classical assumption requirements, so the data does not have to follow a certain distribution, such as a multivariate normal distribution. PLS-PM also avoids multicollinearity problems and autocorrelation problems. It can also be used in research with small samples, can predict models based on weak theories, and can measure using different types of data scales simultaneously (Yamin \& Kurniawan, 2011). In this study, a categorical scale measured the person and place dimensions, while an ordinal Likert scale measured the psychological process dimension $(1=$ strongly disagree, $2=$ disagree, $3=$ neutral, $4=$ agree, $5=$ strongly agree).

The first step in the PLS-PM analysis after determining the constructs and their indicators is to define the measurement model (outer model). At this stage, the researchers defined and specified the relationships between the constructs and the indicators. The researchers designed a structural model (inner model) by formulating the relationships between the constructs, as illustrated in Figure 1.

After determining the model design, the next step was processing the data. In the PLS-PM analysis, researchers used XLSTAT software. After the XLSTAT program processed the model, the next step was to evaluate it. Researchers carried out the PLS model evaluation in stages, first evaluating the measurement model, and then evaluating the structural model. The purpose of evaluating the measure- 
ment model was to assess the validity and reliability of the constructs. Structural model evaluation aimed to determine and predict the correlation between constructs. Table 3 outlines the stages in the model evaluation.

Table 3. Examination Parameters

\begin{tabular}{|c|c|c|c|}
\hline $\begin{array}{l}\text { Evaluation } \\
\text { Stage }\end{array}$ & Examination & Parameter & Rules of Thumb \\
\hline \multirow{9}{*}{$\begin{array}{l}\text { Outer model } \\
\text { (measuremen } \\
\text { t) evaluation }\end{array}$} & Individual & \multicolumn{2}{|c|}{ Standardized Loading factor $>$} \\
\hline & & \multirow{2}{*}{$\begin{array}{l}\text { y loading } \\
\text { factor }\end{array}$} & 0.7 (ideal) \\
\hline & & & $\begin{array}{l}\text { Loading factor > } \\
0.5 \text { (acceptable) }\end{array}$ \\
\hline & Level of & \multirow[t]{2}{*}{ Critical ratio } & Critical ratio $>$ \\
\hline & $\begin{array}{l}\text { Significance } \\
\text { of loading } \\
\text { factor }\end{array}$ & & 2.0 \\
\hline & $\begin{array}{l}\text { Internal } \\
\text { consistency } \\
\text { reliability }\end{array}$ & $\begin{array}{l}\text { Cronbach's } \\
\text { alpha / D.G. } \\
\text { rho (PCA) }\end{array}$ & $\begin{array}{l}\text { Cronbach's } \\
\text { alpha > } 0.7 \\
\text { D.G. rho (PCA) } \\
>0.7\end{array}$ \\
\hline & $\begin{array}{l}\text { Examination } \\
\text { of average } \\
\text { variance } \\
\text { extracted } \\
\text { (AVE) }\end{array}$ & $\begin{array}{l}\text { Average } \\
\text { variance } \\
\text { extracted }\end{array}$ & $\begin{array}{l}\text { Average } \\
\text { variance } \\
\text { extracted }>0.5\end{array}$ \\
\hline & $\begin{array}{l}\text { Discriminant } \\
\text { validity }\end{array}$ & $\begin{array}{l}\text { Cross } \\
\text { loading }\end{array}$ & $\begin{array}{l}\text { Loading factor } \\
\text { indicators of its } \\
\text { construct }> \\
\text { loading factor in } \\
\text { another construct }\end{array}$ \\
\hline & & $\begin{array}{l}\text { Comparison } \\
\text { of AVE } \\
\text { values with } \\
\text { correlation } \\
\text { square } \\
\text { between } \\
\text { constructs }\end{array}$ & $\begin{array}{l}\text { AVE > } \\
\text { correlation } \\
\text { square between } \\
\text { constructs }\end{array}$ \\
\hline \multirow{5}{*}{$\begin{array}{l}\text { Inner model } \\
\text { (structural) } \\
\text { evaluation }\end{array}$} & \multirow[t]{2}{*}{$\begin{array}{l}\text { Path } \\
\text { coefficient }\end{array}$} & t statistic & $\begin{array}{l}\mathrm{t} \text { statistic }>1.64 \\
\text { (one-tailed) }\end{array}$ \\
\hline & & \multicolumn{2}{|c|}{$\begin{array}{l}\text { Critical ratio } \mathrm{CR}>2.0 \\
(\mathrm{CR})\end{array}$} \\
\hline & $\begin{array}{l}\text { Variability of } \\
\text { endogen } \\
\text { constructs }\end{array}$ & $\mathrm{R}^{2}$ & $\begin{array}{l}0.67 \text { (strong) } \\
0.33 \text { (moderate) } \\
0.19 \text { (weak) }\end{array}$ \\
\hline & $\overline{\text { Effect size }}$ & $\mathrm{f}^{2}$ & $\begin{array}{l}0.02 \text { (weak) } \\
0.15 \text { (medium) } \\
0.35 \text { (strong) }\end{array}$ \\
\hline & $\begin{array}{l}\text { Goodness of } \\
\text { Fit }\end{array}$ & GoF absolute & $\begin{array}{l}0.10 \text { (low) } \\
0.25 \text { (moderate) } \\
0.36 \text { (high) }\end{array}$ \\
\hline
\end{tabular}

(Source: Yamin \& Kurniawan, 2011)

When indicators have a loading factor value less than the rule of thumb, researchers remove these indicators from the design of the first model, leaving an indicator that has a value in accordance with the loading factor requirements for each construct and resulting in a second model design. The second model is an evaluation of the re-measurement model. If in the evaluation of the measurement model, both models meet the requirements for each examination item, then the evaluation of the structural model can proceed. The last stage is interpreting the model the researchers have built to answer the research question.

\section{RESULTS AND DISCUSSION}

\section{Evaluation of the First Level Measurement Model}

The initial evaluation of the measurement model of the PLS-PM result examines the correlation between each construct and its indicators. In this case, it is the correlation between each place attachment dimension and each indicator. The first level of measurement includes checking individual item reliability. The standardized loading factor value measures each item's reliability by describing the magnitude of the correlation between each indicator (manifest variable) and its construct (latent variable). A loading factor value above 0.7 is ideal because the indicator is valid in measuring the construct. A loading factor value above 0.5 is also acceptable, but if one indicator has a loading factor value below 0.5 , it can be excluded from the model.

The "Corr" value is the standardized loading factor value between the indicator and the construct. For example, the magnitude of the correlation value between the age indicator (X1.1) and the person dimension construct is 0.923 , while that between the number of dwelling indicator (X2.2) and the place dimension construct is 0.096 .

Based on the first iteration, the indicators of age, length of stay, and cultural/ritual practices have Corr values of more than 0.5 in measuring the construct of the person dimension and are valid indicators. The indicators of the intensity of social interactions and stay plan are valid as measuring tools for the construct of the place dimension. Nearly all of the indicators for the psychological process dimension were valid indicators, except for the pride indicator (Y3.7). The critical ratio (CR) value provides a test of the significance level of the loading factor. A critical ratio value above 2.0 indicates that the loading factor of the indicator is significant. Based on the output results, all valid indicators for the construct have a critical ratio value above 2.0; so, all indicators can be considered significant.

The results of the first iteration show that time aspects, specifically age, length of stay, and beliefs in carrying out cultural/ritual practices, can reflect the person dimension empirically in relation to the dwellers' psychological process dimension. Social 


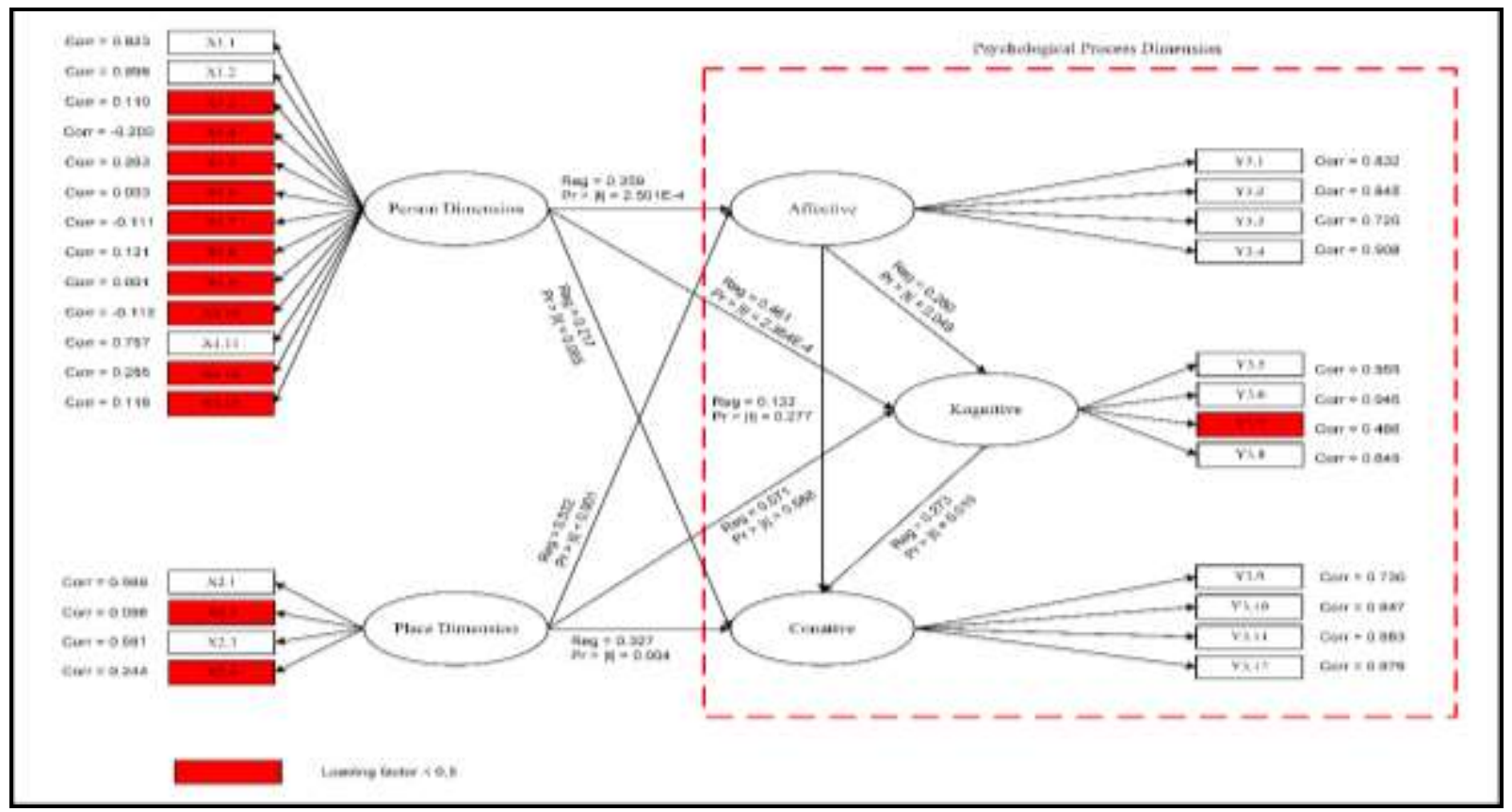

Fig. 2. The First Iteration Result Mode

status, mobility, pedigree, and history of damage do not have a valid relationship with the person dimension in influencing the psychological process dimension. This result shows that the person dimension characterizes the dwellers' experiences over time, thus creating a long-term relationship with the Joglo house they occupy. Figure 2 illustrates the first model of PLS-PM results using XLSTAT.

The person dimension is also reflected in the belief, passed down from generation to generation, that defines Joglo not only as a space with a physical dimension but also as a place where the jagad cilik (microcosm) and the jagad gedhe (macrocosm) are united. Even though there has been a shift in carrying out Javanese traditional beliefs/rituals due to the influence of Islam and changes in the sacred place in some Joglo houses, it is still possible to use the dwellers' beliefs as a measuring tool for the person dimension.

The place dimension reflects the intensity of the dwellers' social interactions with the environment through various activities and also their plan for the Joglo in the future. Table 4 presents the overall loading factor value for each variable.

Indicators that have a loading factor value below 0.5 are invalid and must be removed from the measurement model. After their removal, the second level evaluation of the measurement model (outer model) and the evaluation of the structural model (inner model) can proceed.
Table 4. Correlations

\begin{tabular}{|c|c|c|c|c|}
\hline \multicolumn{2}{|c|}{ Latent Variable } & $\begin{array}{l}\text { Manifest } \\
\text { Variables }\end{array}$ & $\begin{array}{c}\text { Standardized } \\
\text { Loadings }\end{array}$ & $\begin{array}{c}\text { Critical } \\
\text { Ratio (CR) }\end{array}$ \\
\hline \multirow{13}{*}{\multicolumn{2}{|c|}{ Person Dimension }} & $\mathrm{X} 1.1$ & 0.923 & 29.358 \\
\hline & & $\mathrm{X} 1.2$ & 0.898 & 18.624 \\
\hline & & $\mathrm{X} 1.3$ & 0.110 & 0.541 \\
\hline & & X1.4 & -0.200 & -1.426 \\
\hline & & $\mathrm{X} 1.5$ & 0.263 & 1.497 \\
\hline & & X1.6 & 0.003 & 0.011 \\
\hline & & $\mathrm{X} 1.7$ & -0.111 & -0.465 \\
\hline & & $\mathrm{X} 1.8$ & 0.121 & 0.496 \\
\hline & & X1.9 & 0.001 & 0.003 \\
\hline & & $\mathrm{X} 1.10$ & -0.112 & -1.420 \\
\hline & & X1.11 & 0.757 & 9.847 \\
\hline & & $\mathrm{X} 1.12$ & 0.286 & 2.191 \\
\hline & & $\mathrm{X} 1.13$ & 0.118 & 0.825 \\
\hline \multirow{5}{*}{\multicolumn{2}{|c|}{ Place Dimension }} & $\mathrm{X} 2.1$ & 0.989 & 96.476 \\
\hline & & $\mathrm{X} 2.2$ & 0.096 & 0.607 \\
\hline & & $\mathrm{X} 2.3$ & 0.581 & 2.890 \\
\hline & & $\mathrm{X} 2.4$ & 0.244 & 1.296 \\
\hline & & Y3.1 & 0.832 & 12.941 \\
\hline \multirow{11}{*}{$\begin{array}{l}\text { Psychological } \\
\text { Process } \\
\text { Dimension }\end{array}$} & \multirow{3}{*}{ Affective } & Y3.2 & 0.845 & 9.442 \\
\hline & & Y3.3 & 0.720 & 4.012 \\
\hline & & Y3.4 & 0.908 & 26.463 \\
\hline & \multirow{4}{*}{ Cognitive } & Y3.5 & 0.569 & 7.420 \\
\hline & & Y3.6 & 0.946 & 42.079 \\
\hline & & Y3.7 & 0.486 & 5.212 \\
\hline & & Y3.8 & 0.649 & 6.421 \\
\hline & \multirow{4}{*}{ Conative } & Y3.9 & 0.730 & 7.650 \\
\hline & & Y3.10 & 0.847 & 13.718 \\
\hline & & Y3.11 & 0.883 & 22.615 \\
\hline & & Y3.12 & 0.879 & 20.629 \\
\hline
\end{tabular}




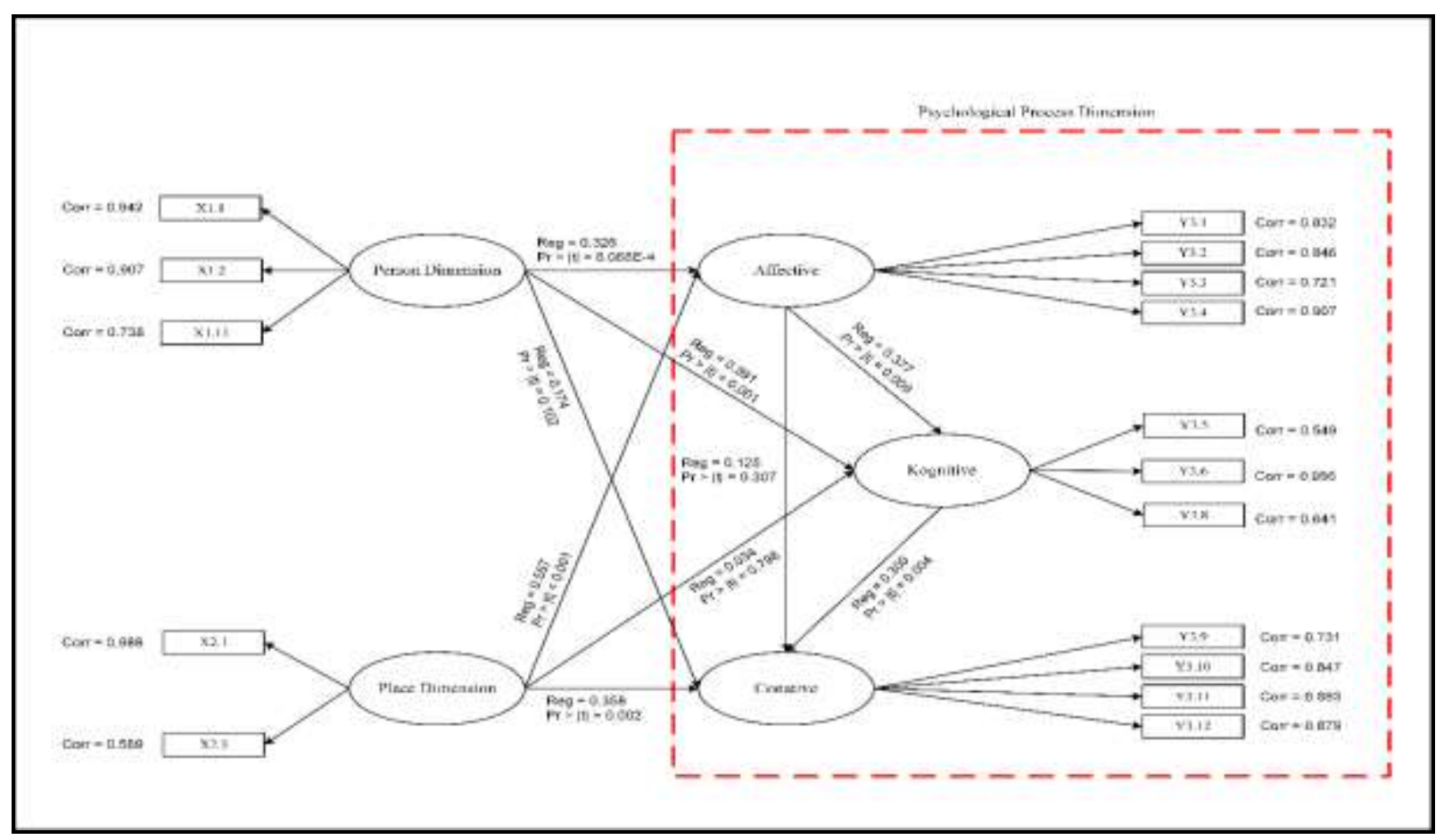

Fig. 3. The Second Iteration Result Model

\section{Evaluation of the Second Level of Measurement Model (Outer Model)}

The second model, shown in Figure 3, illustrates the relationships among the person dimension, the place dimension, and the psychological process dimension with only those constructs that have valid indicators. After checking the reliability of individual items, the evaluation of the second level measurement model continued with an examination of the internal consistency reliability and average variance extracted (AVE) measurements (see Table 5).

Based on the results of the PLS-PM process, the three constructs of person, place, and psychological process dimensions had Cronbach's alpha and D.G. rho (PCA) values above 0.7; except for the Cronbach's alpha value for the place dimension and the cognitive aspects of the psychological process dimension. Although their Cronbach's alpha values were less than 0.7; they had D.G. rho (PCA) values or composite reliability greater than 0.7 , so the place dimension and cognitive aspects can still be used as constructs that have high reliability as measurement tools. The same is true for the person dimension and the affective and conative aspects in the psychological process dimension.

The next step in evaluating the measurement model is an examination of the average variance extracted (AVE) values. AVE measures the amount of variance or the diversity of indicators that the construct contains compared to the variance of the measurement error results. Based on the results of the assessment model table, each of the five constructs had an AVE value greater than 0.5, indicating that the construct had good convergent validity.

Table 5. AVE

\begin{tabular}{|c|c|c|c|}
\hline Latent variable & $\begin{array}{l}\text { Cronbach's } \\
\text { alpha }\end{array}$ & $\begin{array}{l}\text { D.G. rho } \\
\text { (PCA) }\end{array}$ & AVE \\
\hline Person Dimension & 0.828 & 0.921 & 0.752 \\
\hline Place Dimension & 0.535 & 0.899 & 0.662 \\
\hline Psychological Affective & 0.850 & 0.907 & 0.688 \\
\hline Cognitive & 0.597 & 0.862 & 0.542 \\
\hline Dimension & 0.858 & 0.909 & 0.701 \\
\hline
\end{tabular}

After the convergent validity check, the next step was examining discriminant validity by checking the cross-loading value and comparing the AVE value with the correlation square between the constructs. As reported in Table 6, the loading factor value of each indicator for each construct was higher than for the other constructs, which indicates that the construct was able to predict each indicator well. For example, the loading factor value for the age indicator (X1.1) was 0.942 for the person dimension construct, a higher value than its values for the place dimension construct $(0.550)$ or the affective aspects of the psychological process dimension construct (0.548). The cross-loading inspection of the overall model met the requirements. 
Table 6. Cross-Loading

\begin{tabular}{lrrrrr}
\hline & Person & Place & \multicolumn{4}{c}{ Psychological Process Dimension } \\
\cline { 5 - 7 } & Dimension & Dimension & Affective & Cognitive & Conative \\
\hline$X 1.1$ & $\mathbf{0 . 9 4 2}$ & 0.550 & 0.548 & 0.618 & 0.634 \\
$X 1.2$ & $\mathbf{0 . 9 0 7}$ & 0.547 & 0.544 & 0.507 & 0.573 \\
$X 1.11$ & $\mathbf{0 . 7 3 8}$ & 0.659 & 0.662 & 0.713 & 0.642 \\
\hline$X 2.1$ & 0.639 & $\mathbf{0 . 9 8 8}$ & 0.718 & 0.574 & 0.705 \\
$X 2.3$ & 0.351 & $\mathbf{0 . 5 8 9}$ & 0.563 & 0.298 & 0.563 \\
\hline$Y 3.1$ & 0.538 & 0.575 & $\mathbf{0 . 8 3 2}$ & 0.538 & 0.553 \\
$Y 3.2$ & 0.552 & 0.663 & $\mathbf{0 . 8 4 6}$ & 0.447 & 0.661 \\
$Y 3.3$ & 0.415 & 0.553 & $\mathbf{0 . 7 2 1}$ & 0.359 & 0.546 \\
$Y 3.4$ & 0.667 & 0.710 & $\mathbf{0 . 9 0 7}$ & 0.711 & 0.635 \\
\hline$Y 3.5$ & 0.486 & 0.323 & 0.341 & $\mathbf{0 . 5 4 9}$ & 0.449 \\
$Y 3.6$ & 0.555 & 0.509 & 0.570 & $\mathbf{0 . 9 5 6}$ & 0.594 \\
$Y 3.8$ & 0.627 & 0.492 & 0.565 & $\mathbf{0 . 6 4 1}$ & 0.552 \\
\hline$Y 3.9$ & 0.541 & 0.480 & 0.576 & 0.633 & $\mathbf{0 . 7 3 1}$ \\
$Y 3.10$ & 0.610 & 0.648 & 0.568 & 0.548 & $\mathbf{0 . 8 4 7}$ \\
$Y 3.11$ & 0.588 & 0.659 & 0.602 & 0.528 & $\mathbf{0 . 8 8 3}$ \\
$Y 3.12$ & 0.590 & 0.653 & 0.663 & 0.681 & $\mathbf{0 . 8 7 9}$ \\
\hline
\end{tabular}

In addition to comparing the loading factor values, researchers also examined discriminant validity based on the comparison of the AVE value with the correlation square between the constructs. In this examination, detailed in Table 7, the AVE value of each construct was greater than the square of the correlation between it and other constructs.

Table 7. Discriminant Validity

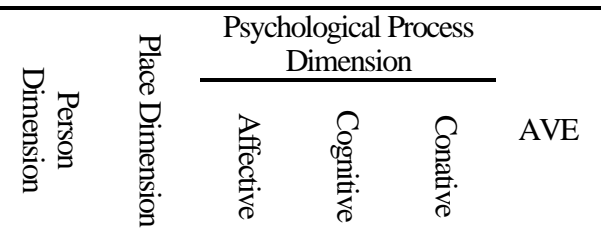

\begin{tabular}{|c|c|c|c|c|c|c|}
\hline $\begin{array}{l}\text { Person } \\
\text { Dimension }\end{array}$ & 1 & 0.41 & 0.46 & 0.45 & 0.47 & 0.75 \\
\hline Place Dimension & 0.41 & 1 & 0.58 & 0.33 & 0.54 & 0.66 \\
\hline 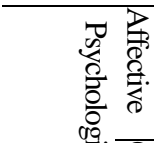 & 0.46 & 0.58 & 1 & 0.45 & 0.52 & 0.69 \\
\hline 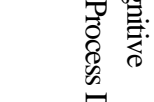 & 0.45 & 0.33 & 0.45 & 1 & 0.50 & 0.54 \\
\hline 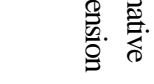 & 0.47 & 0.54 & 0.52 & 0.50 & 1 & 0.70 \\
\hline AVE & 0.75 & 0.66 & 0.69 & 0.54 & 0.70 & 0 \\
\hline
\end{tabular}

The evaluation of the second measurement model (outer model) reached several conclusions. First, the age of the dwellers, their length of stay, and the cultural/ritual practices they performed could reflect or measure the person dimension. Second, the intensity of the dwellers' social interactions with the environment around the Joglo and their plans for their house could reflect the place dimension. Third, me- mories (ownership of memories), residency (staying), users (house inheritance), and special bonds (ownership of special connections) could measure the affecttive aspects of the psychological process dimension. Fourth, meaning (worth), identification (historical knowledge), and commitment (sense of responsibility) could measure the cognitive aspects of the psychological process dimension. Finally, four indicators - activities (support for daily activities), best (comfort), preference (comparison with other housing), and satisfaction - could reflect the conative aspects of the psychological process dimension. After learning which indicators could reflect or serve as a valid measuring tool for each construct, the next step was to evaluate the structural model (inner model) to determine the correlation among constructs, specifically the correlations between person dimension and place dimension and each of the aspects of the psychological process dimension.

\section{Structural Model Evaluation}

Researchers divided the structural model testing into three examinations of correlations of (1) the person and place dimensions with the affective aspects, (2) the person and place dimensions and the affective aspects with the cognitive aspects, and (3) the person and place dimensions and the affective and cognitive aspects with the conative aspects.

The first examination, which measured the correlation of the person and place dimension with the affective aspects, showed that the $t$ statistical value for the construct of the person dimension was 3.505 with a p-value of $0.001<0.05$ with a critical ratio (CR) value of 2.824. Therefore, the person dimension has a positive significance to the affective aspects of the psychological process dimension. The $\mathrm{t}$ statistical value for the place dimension construct was 6.002 with a p-value of $0.000<0.05$ with a $C R$ value of 4.093. The place dimension also had a significant positive effect on the affective aspects of the psychological process dimension. Simultaneously, the constructs of the person dimension and the place dimension influenced the affective aspects of the psychological process dimension. These results allowed researchers to generate an equation model between the constructs of the person and place dimensions and the affective aspects of the psychological process dimension.

Equation of the model:

Affective $=0.326 *$ person dimension $+0.557 *$ place dimension

Based on the model, the affective aspects were positively influenced by the person and place dimensions. Both the person dimension and the place dimension coefficients were positive, indicating that an increase in the value of either or both of the two 
dimensions would increase the value of the affective aspects of the psychological process dimension. The model produced a greater coefficient for the place dimension than for the person dimension. This result suggests that changes to the place dimension have a greater influence on the value of the affective aspects, compared to changes to the person dimension. The basic data for each person and place dimension indicator in the form of categorical data makes it difficult to determine the real value of such changes. However, in general, it appears that if the intensity of social interaction between dwellers and their neighbors and the decision to stay in the Joglo house is high, then the value of the affective aspects will be higher. This result displays itself in the form of a stronger level of social bonding or dwellers' attachment based on a sense of ownership formed during the stay. The person dimension also influenced the affective aspects, indicating that older dwellers who have lived longer in their houses and are still routinely carrying out various forms of cultural/ritual practices have stronger levels of social bonding to their Joglo.

Based on the R2 value of 0.649 , the constructs of the person dimension and the place dimension explained $64.9 \%$ of the variability of the affective aspects of the psychological process dimension construct, while other constructs influenced the remaining $35.1 \%$. An R2 value greater than 0.33 is classified as a moderate influence. The person dimension construct contributed $34.234 \%$, substantially lower than the place dimension construct, which contributed $65.766 \%$. Another useful assessment tool is the value of the effect size $f^{2}$. The value of the effect size $f^{2}$ for the person dimension construct was 0.178 and that for the place dimension construct was 0.522 . An $\mathrm{f}^{2}$ value greater than 0.15 indicates a moderate effect on the structural level, while an $\mathrm{f}^{2}$ value greater than 0.35 indicates a large influence on the structural level.

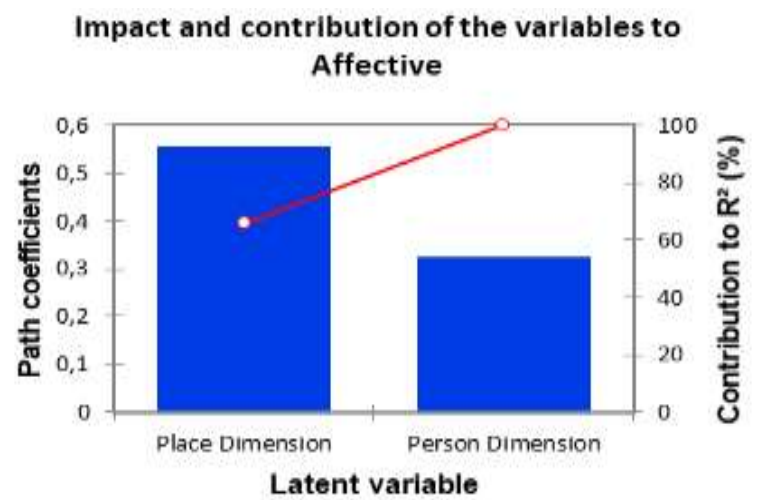

Path coefficient $\longrightarrow$ Cumulative \%

Fig. 4. Impact and Contribution of the Variables to Affective Aspects
The second examination concerned the correlation of the person dimension, the place dimension, and the affective aspects to the cognitive aspects of the psychological process dimension. Examination of the path coefficient through the $t$ statistical value and the critical ratio of the person and place dimension and affective aspects to the cognitive aspects concluded that the person dimension construct had a statistical $t$ value of 3.342 with a p-value of $0.001<$ 0.05 and a CR value of 3.401. Therefore, the person dimension had a positive significance to the cognitive aspects of the psychological process dimension. The $t$ statistical value for the place dimension construct was 0.034 with a p-value of $0.798>0.05$ and a CR value of 0.230 . Based on these results, the place dimension did not have a significant effect on the cognitive aspects of the dwellers. Meanwhile, the affective aspects had a t statistical value of 2.696 with a p-value of $0.009<0.05$ and a CR value of 2.774 . These results support the following equation for the influence of the person and place dimensions and the affective aspects on the cognitive aspects of the psychological process dimension.

Equation of the model:

Cognitive $=0.391 *$ person dimension +0.377

$*$ affective aspects $+0.034 *$ place dimension

The model shows that the person dimension and the affective aspects had a similarly significant positive effect on the cognitive aspects. As in the first examination, researchers can use the equation properly if they can calculate the real value of each construct. Since the basic data is categorical, the example can only be expressed in general terms. The values of the coefficients of the constructs show that the person dimension and the affective aspects influence the cognitive aspects in the form of place identity or dweller bonds at almost the same intensity. The older the dwellers are and the longer they stay, and considering their commitment to carrying out various cultural/rituals practices, the higher the possibility of the dwellers' emotional bond with their Joglo is. Thus, it enables the dwellers to differentiate themselves through the unique values of the house. The equation model also suggests that the same form of attachment can strengthen other attachments. For example, an increase in the value of the affective aspects can increase the value of the dwellers' cognitive aspects. This result shows that the dwellers' ownership and their special relationship (social bonding) can increase their emotional bonds (place identity).

The constructs of the person dimension, the place dimension, and the affective aspects were able 
to explain $53.4 \%$ of the variability of the cognitive aspects of the psychological process dimension construct, while other constructs explain the remaining $46.6 \%$. The R2 value of 0.534 is classified as a moderate effect. The person dimension construct made a high contribution of up to $73.757 \%$, compared to the place dimension construct that contributed only $26.243 \%$.

\section{Impact and contribution of the variables to Cognitive}

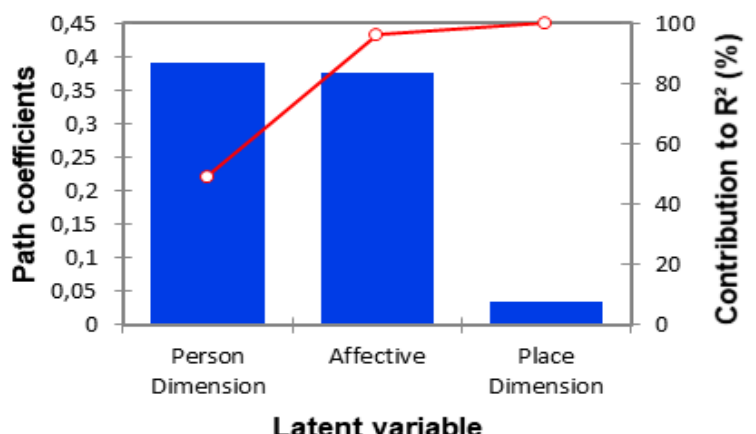

\section{Path coefficient $\multimap$-Cumulative \%}

Fig. 5. Impact and Contribution of the Variables to Cognitive Aspects

That the person dimension made a much higher contribution to the cognitive aspects shows that emotional attachment to a place over time allows Joglo dwellers to differentiate themselves from other people from other places through particularity or uniqueness. The value of the effect size $f^{2}$ provided another assessment. The value of the effect size $\mathrm{f}^{2}$ for the person dimension construct was 0.164, while the affective aspects construct was 0.107 . An $\mathrm{f}^{2}$ of greater than 0.15 indicates a moderate effect on the structural level, but an $\mathrm{f}^{2}$ of greater than 0.02 implies little effect on structural levels.

The third inner model examination focused on the correlation of the person and place dimensions and the affective and cognitive aspects to the conative aspects of the psychological process dimension, carried out by examining the $t$ statistical values and the critical ratios. The person dimension construct had a statistical $t$ value of 1.658 with a p-value of $0.102>$ 0.05 and a CR value of 1.550 ; thus, the person dimension did not have a significant correlation to the conative aspects of the psychological process dimension. The $\mathrm{t}$ statistical value for the place dimension construct was 3.246 with a p-value of $0.002<0.05$ and a CR value of 2.892; the place dimension had a positive significance toward the conative aspects of the psychological process dimension. The affective aspects had a statistical $t$ value of 1.028 with a p-value of $0.307>0.05$ and a CR value of 0.931 ; therefore, the affective aspects had no significant correlation to the conative aspects. Finally, the cognitive aspects had a statistical $t$ value of 2.982 with a p-value of $0.004<$ 0.05 and a CR value of 3.293 , indicating that the cognitive aspects had a significant relationship to the conative aspects.

Equation of the model:

Conative $=0.173 *$ person dimension $+0.353 *$ place dimension $+0.131 *$ affective aspects $+0.299 *$ cognitive aspects

This model equation has the same limitations as those for the previous models. Because the basic data is categorical, making it difficult to calculate based on the coefficient value when one cannot measure the precise value of each construct. In a general sense, the place dimension and the cognitive aspects positively influenced the conative aspects. The increasing intensity of the dwellers' social interactions and the desire to stay in the Joglo can increase the cognitive aspects of the dwellers in the form of functional ties to the Joglo house (place dependence). The increase in cognitive aspects in the form of emotional bonds (place identity) also affects the increase in functional ties to the Joglo.

\section{Impact and contribution of the variables to Conative}

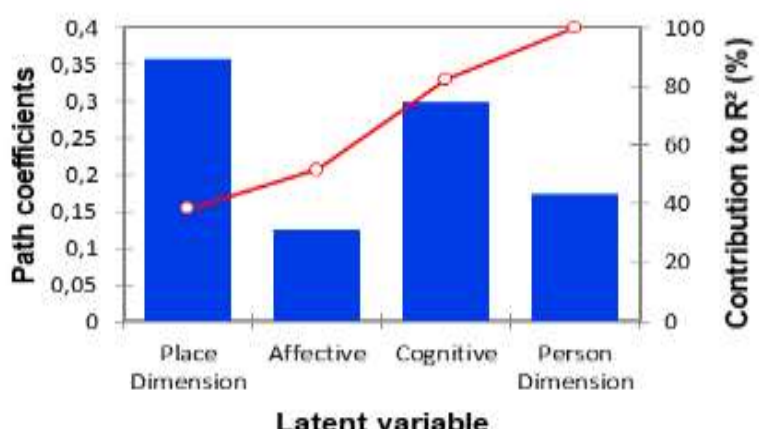

Path coefficient $\quad-\infty$ Cumulative $\%$

Fig. 6. Impact and Contribution of the Variables to Conative Aspects

The place dimension, reflected by familiarity through the intensity of social interactions and stay plans, has a major influence on the cognitive aspects, which is related to the assessment of the Joglo's ability to support the dwellers' daily activities, comfort, preferences, and satisfaction while living in the house. The place dimension explained 38.523\%, while the cognitive aspects explained $30.860 \%$ of the 
variation in the conative aspects. The effect size offers insights into the effects of exogenous and endogenous constructs. The value of the effect size $\mathrm{f}^{2}$ for the place dimension construct was 0.157 , while the value for the cognitive aspects was 0.133 . An $\mathrm{f}^{2}$ value greater than 0.15 indicates a moderate effect on the structural level, while an $\mathrm{f}^{2}$ value greater than 0.02 indicates a small effect. The construct was able to explain $68.5 \%$ of the variability of the conative aspects of the psychological process dimension, while other constructs explained the remaining $31.5 \%$.

The final evaluation of the structural model after testing the exogenous latent constructs with each endogenous latent construct was to examine the goodness of fit (GoF absolute) of the structural model. Based on the GoF index, the structural model has a $\mathrm{GoF}$ value of 0.647 . A GoF value greater than 0.36 means that the model has a high ability to explain empirical data. The structural model was able to explain the empirical conditions related to the correlation between the place attachment dimension of the dwellers and the Joglo house they occupy.

\section{CONCLUSION}

This PLS-PM analysis of measurement models and structural models developed a model that explains place attachment for the dwellers in Joglo. The indicators that best reflected the person dimension were age, length of stay, and cultural/ritual practices. The place dimension was reflected by indicators of the intensity of social interactions and stay plans, while almost all indicators in every aspect of the psychological process dimension could be used as a measuring tool for place attachment, except for the pride indicator.

Not all constructs had a significant correlation to place attachment. The strength of the correlation varied depending on the dimension. For the affective aspects, the place dimension had a greater influence than the person dimension, perhaps because the affective aspects are related to the bonds of ownership and the connection that the dwellers have during their stay. These factors are also related to inheritance plans and social interactions that can minimize conflicts so the dwellers can feel comfortable during their stay. Meanwhile, the person dimension and the affective aspects influenced the cognitive aspects related to the dwellers' emotions. This result suggests that the older the dwellers are, the longer they stay, and the more they participate in various cultural/ritual practices, the stronger their emotional bonds are. In addition, one form of bonding can strengthen other forms of bonding. For example, affective aspects had an influence on cognitive aspects, in which bonds are formed because of a sense of belonging and a special relationship that can strengthen the dwellers' emotional bond with their Joglo. Finally, the conative aspects related to function were most influenced by the place dimension and cognitive aspects. This result shows that stay plans, social interactions, and selfidentification are related to assessing the satisfaction, comfort, preferences, and the ability of the Joglo house to support the dwellers' activities.

\section{REFERENCES}

Abdillah, W., Jogiyanto. (2015). Partial Least Square (PLS): Alternatif Structural Equation Modeling (SEM) dalam Penelitian Bisnis. Yogyakarta: ANDI.

Chen, N., Šegota, T. (2015). Resident Attitudes, Place Attachment and Destination. Journal of Tourism and Hospitality Management. 21, 145-158.

Fried, M. (2000). Continuities and discontinuities of place. Journal of Environmental Psychology. 20, 193-205.

Goussous, J.S. \& Al-Hammadi, Nessma. (2018). Place attachment assessment of a heritage place: A case study of the Roman amphitheater in downtown Amman, Jordan. Frontiers of Architectural Research. 7, 1-10.

Inalhan, G., Finch, E. (2004). Place attachment and sense of belonging. Facilities. 22, 120-128.

Jogja Heritage Society. (2007). Homeowner's Conservation Manual. Jakarta: UNESCO.

Jorgensen, B.S., Stedman, R. (2001). Sense of place as an attitude: lakeshoreproperty owners' attitudes toward their properties. Journal of Environmental Psychology. 21, 233-248.

Kyle, G., Mowen, A.J. \& Tarrant, M. (2004). Linking place preferences with place meaning: an examination of the relationship between place motivation and place attachment. Journal of Environmental Psychology. 24, 439-454.

Lewicka, Maria. (2005). Ways to Make People Active: The Role of Place Attachment, Cultural Capital, and Neighborhood Ties. Journal of Environmental Psychology. 25, 381-395.

Lewicka, Maria. (2014). Memory as enabler of place attachment. Place attachment. Advances in theory, methods and applications. 49-60.

Low S.M., Altman I. (1992). Place Attachment. In: Altman I., Low S.M. Place Attachment. "Human Behavior and Environment (Advances in Theory and Research)", Vol.12. Springer. Boston. MA.

Mazumdar, Shampa \& Mazumdar, Sanjoy. (2004). Religion and Place Attachment: A Study of Sacred Places. Journal of Environmental Psychology. 24, 385-397. 
Ronald, Arya. (2005). Nilai-Nilai Arsitektur Rumah Tradisional Jawa. Yogyakarta: UGM Press.

Scannell, L., \& Gifford, R. (2010). Defining place attachment: A tripartite organizing framework. Journal of Environmental Psychology. 30, 1-10.

Scannell, L., \& Gifford, R. (2014). The psychology of place attachment. In: Gifford, R. Environmental Psychology Principles and Practice. Chapter 9. Optimal Books.

SK Gubernur DIY No. 186/KEP/2011 tentang Penetapan Kawasan Cagar Budaya.

Stedman, R. C. (2002). Toward a Social psychology of place: predicting behaviour from place-based cognitions, attitude, and identity. Journal of Environment \& Behaviour. 34, 561-581.

Subiyantoro, Slamet. (2011). Rumah Tradisional Joglo dalam Estetika Tradisi Jawa. Jurnal Bahasa dan Seni. 39, 69-78.

Ujang, Norsidah. (2012). Place Attachment and Continuity of Urban Place Identity. Social and Behavioral Sciences. 49, 156-167.

Utomo, Prasetyo. (2014). Culture of Dwelling and Production of Space in the Post - Disaster Urban Transformation Processes (Case Study:
Kotagede, Yogyakarta - Indonesia). Berlin: Berlin University.

Williams, D.R., Patterson, M.E., Roggenbuch, J.W. \& Watson, A.E. (1992). Beyond the commodity metaphor: examining emotional and symbolic attachment to place. Journal of Leisure Science. 14, 29-46.

Williams, Daniel \& Vaske, Jerry. (2003). The Measurement of Place Attachment: Validity and Generalizability of a Psychometric Approach. Journal of Forest Science. 49, 830-840.

Yamin, S., Kurniwan, H. (2011). Generasi Baru Mengolah Data Penelitian dengan Partial Least Square Path Modeling: Aplikasi dengan Software XLSTAT, SmartPLS, dan Visual PLS. Jakarta: Salemba Infotek.

Yetti, Aprodita E. (2018). Preservasi Kawasan Perdagangan Ktagede Yogyakarta Dengan Pendekatan Adaptive Reuse. Jurnal Arsitektir dan perencanaan. 1, 14-26.

Yuksel, A., uksel, F. \& Bilim, Y. (2010). Destination attachment: effects on customer satisfaction and cognitive, affective and conative loyalty. Journal of Tourism Management. 31, 274-284. 